\title{
BUDAYA INFORMASI PADA SISWA BERKEBUTUHAN KHUSUS (STUDI KASUS PADA SEKOLAH PENYELENGGARA PENDIDIKAN LUAR BIASA DI PROVINSI BALI)
}

\author{
Richard Togaranta Ginting1 \\ Program Studi D3 Perpustakaan \\ Fakultas Ilmu Sosial dan Ilmu Politik \\ Universitas Udayana \\ Email: richardtogaranta@unud.ac.id
}

\begin{abstract}
ABSTRAK
Penelitian ini bertujuan untuk mengetahui budaya informasi pada siswa berkebutuhan khusus. Jenis penelitian yang digunakan dalam penelitian ini adalah penelitian kuantitatif deskriptif. Penelitian ini berusaha mengungkapkan dan menjelaskan secara deskriptif mengenai budaya informasi pada siswa berkebutuhan khusus. Khususnya pada siswa pendidikan luar biasa di provinsi Bali. Teknik pengambilan sampel dilakukan dengan stratified random sampling. Jumlah sampel yang diteliti berasal dari sekolah penyelenggara pendidikan luar di provinsi Bali, yakni SLB Negeri 1 Denpasar, SLB Negeri 1 Singaraja dan SLB Negeri 1 Tabanan. Berdasarkan hasil perhitungan ditentukan sebanyak 152 responden. Penelitian ini memberikan gambaran mengenai budaya informasi yang dimulai dengan cara mendapatkan informasi, mengolah informasi hingga memanfaatkan informasi untuk pengambilan keputusan pada siswa berkebutuhan khusus.
\end{abstract}

Kata kunci: budaya informasi, siswa berkebutuhan khusus, sekolah luar biasa

\begin{abstract}
This study aims to determine the information culture for students with special needs. The type of research used in this study is descriptive research with survey approaching. This research attempts to reveal and explain descriptively about the information culture for students with special needs. The sampling technique is done by purposive sampling. The number of samples studied originated from extraordinary schools in the bali province, namely are SLB Negeri 1 Denpasar, SLB 1 Singaraja and SLB 1 Tabanan . Based on the results of calculations determined as many as 152 respondents. This study provides an overview of the information culture that begins with how to obtain information, process information to utilize information for decision making on students with special needs.
\end{abstract}

Keywords: information culture, students with special needs, extraordinary schools

\section{PENDAHULUAN}

Seiring dengan berkembangnya zaman, budaya informasi menjadi hal yang sangat penting untuk meningkatkan standar literasi informasi seseorang dalam menggunakan informasi. Budaya informasi yang literat menjadi tren yang dimiliki oleh setiap orang saat ini. Tidak terkecuali oleh siswa berkebutuhan khusus. Siswa berkebutuhan khusus memiliki pola pencarian, pengolahan dan pemanfaataan yang sangat menarik. 
Budaya informasi pada siswa berkebutuhan khusus dapat dilihat melalui bagaimana siswa melakukan pencarian informasi yang biasa didapatkan dari koleksi khusus yang ada di perpustakaan. Tidak seperti koleksi umum yang terkesan biasa, koleksi khusus ini disesuaikan dengan kemampuan siswa dalam keterbatasan fisik yang mereka miliki. Kita mengenal koleksi khusus seperti koleksi braille. selain itu, setelah melakukan pencarian informasi, terdapat kegiatan yang dilakukan oleh siswa berkebutuhan khusus dalam mengolah informasi yang mereka peroleh. Berdasarkan observasi pendahuluan yang dilakukan oleh peneliti, didapatkan fakta bahwa pengolahan informasi oleh siswa berkebutuhan khusus dilakukan secara mendalam berdasarkan karakteristik psikologis siswa. Selanjutnya, pemanfaatan informasi yang diperoleh umumnya para siswa berkebutuhan khusus menjadikan informasi tersebut sebagai dasar pengambilan keputusan secara hati-hati.

Berdasarkan beberapa fenomena-fenomena di atas, peneliti tertarik untuk melakukan penelitian dengan judul penelitian "Budaya Informasi pada Siswa Berkebutuhan Khusus (Studi Kasus pada Sekolah Penyelenggara Pendidikan Luar Biasa di Provinsi Bali)”. Penelitian ini bertujuan untuk mengetahui budaya informasi pada siswa berkebutuhan khusus (studi kasus pada sekolah penyelenggara pendidikan luar biasa di Provinsi Bali.

Kebutuhan informasi menurut Sulistyo-Basuki (2004: 396) ditentukan oleh lima faktor, yaitu 1) kisaran informasi yang tersedia; 2) penggunaan informasi yang akan digunakan; 3) Latar belakang, motivasi, orientasi profesional, dan karakteristik masingmasing pemakai;4) Sistem sosial, ekonomi, dan politik tempat pemakai berada; dan 5) Konsekuensi penggunaan informasi. Berdasarkan pendapat di atas dapat dilihat bahwa kisaran informasi yang tersedia maksudnya bahwa informasi yang diperoleh mempengaruhi kebutuhan informasinya sendiri. Penggunaan informasi yang akan digunakan juga akan mempengaruhi kebutuhan informasi seseorang, misalnya seorang pelajar akan menggunakan informasi yang dia dapatkan di internet sebagai bahan pendukung tugas di sekolah. Ginman dalam Wang (2005:213) mendefinisikan budaya informasi sebagai: Transformation of intellectual resources is maintained alongside the transformation of material resources. The primary resources for this type of transformation are varying kinds of knowledge and information. The output achieved is a processed intellectual product which is necessary for the material activities to function and develop positively. Pendapat lain dikemukakan oleh Marchand dalam Suroso (1996:1) adalah mencakup nilai-nilai, sikap dan perilaku yang mempengaruhi orang dalam perusahaan tersebut di dalam segenap cara pandang, mengumpulkan, mengorganisasi, memproses, menggunakan dan mengkomunikasikan 
informasi. Berdasarkan berbagai pendapat di atas dapat disimpulkan bahwa budaya informasi adalah pola kecenderungan seseorang mulai dari mencari, menelusur dan memanfaatkan informasi untuk membantu dalam menyelesaikan pekerjaan atau tugas tertentu.

\section{Metode Penelitian}

Jenis penelitian ini adalah kuantitatif deskriptif, dimana seluruh data yang diperoleh akan dijelaskan disajikan dalam bentuk table dan dideskripsikan sesuai dengan pertanyaan kuesioner. Lokasi penelitian ini berada pada sekolah-sekolah penyelenggara pendidikan luar biasa di provinsi Bali, yakni: SLB Negeri 1 Denpasar, SLB Negeri 1 Tabanan dan SLB Negeri 1 Singaraja. Populasi dalam penelitian seluruh siswa yang ada di sekolah-sekolah penyelenggara pendidikan luar biasa di provinsi Bali, yakni: SLB Negeri 1 Denpasar, SLB Negeri 1 Tabanan dan SLB Negeri 1 Singaraja. Dengan menggunakan purposive sampling, diperoleh besar sampel sebanyak 152 responden. Analisis data yang diperoleh diambil dalam menyusun ke dalam tabel kemudian dihitung persentasenya, selanjutnya dianalisis dan diinterpretasikan. Penelitian ini menggunakan rumusan sebagai berikut:

$$
\mathrm{P}=\mathrm{F} / \mathrm{n}
$$

Keterangan:

$\mathrm{P}=$ Persentase

$\mathrm{F}=$ Jumlah jawaban yang diperoleh

$\mathrm{n}=$ Jumlah responden

\section{Teknik Pengolahan Data}

Teknik pengolahan data dalam penelitian ini adalah menggunakan persentase, persentase data digunakan untuk melihat besar kecilnya frekuensi jawaban dalam kuesioner yang dihitung dalam jumlah persentase. Karakteristik responden digambarkan pada tabel 1 di bawah ini

Tabel 4.1 Jenis Kelamin Responden

\begin{tabular}{|l|l|l|l|}
\hline No & Jenis kelamin & Jumlah & Persentase \\
\hline 1. & Laki-laki & 75 & $40 \%$ \\
\hline 2. & Perempuan & 77 & $60 \%$ \\
\hline
\end{tabular}

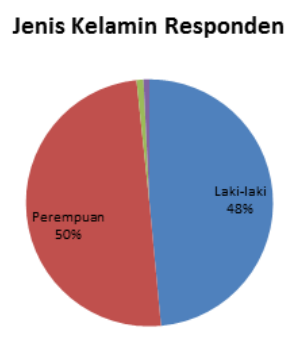




\begin{tabular}{|l|l|l|}
\hline Total & 152 & $100 \%$ \\
\hline
\end{tabular}

Selanjutnya, Berdasarkan data yang diperoleh, klasifikasi usia responden adalah sebagai berikut:

Tabel Usia Responden

\begin{tabular}{|l|l|l|l|}
\hline No & Usia & Jumlah & Persentase \\
\hline 1. & $<13$ tahun & 52 & $34 \%$ \\
\hline 2. & $13-15$ tahun & 65 & $42 \%$ \\
\hline 3. & $>15$ tahun & 35 & $24 \%$ \\
\hline \multicolumn{2}{|l|}{ Total } & 152 & $100 \%$ \\
\hline
\end{tabular}

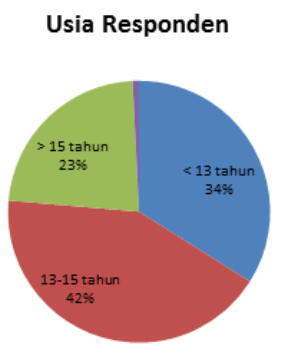

\section{Hasil dan Pembahasan}

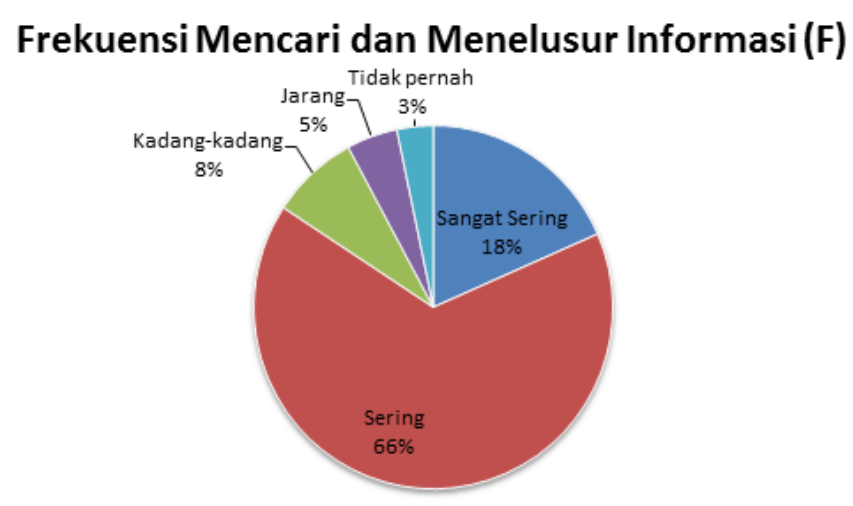

Berdasarkan tabel di atas dengan total persentase 100\% dan responden sebanyak 152 orang menghasilkan jabaran sebagai berikut, sebanyak 28 responden (18\%) sangat sering mencari dan menelusur informasi dan sebanyak 100 responden $(66 \%)$ sering mencari dan menelusur informasi. Selain itu, sebanyak 12 responden (8\%) menyatakan kadang-kadang mencari dan menelusur informasi dan sebanyak 7 responden (5\%) menyatakan jarang mencari dan menelusur informasi. Terakhir, hanya 5 responden $(3 \%)$ yang menyatakan tidak pernah mencari dan menelusur informasi. Kesimpulan dari tabel dan diagram di atas menunjukkan bahwa persentase tertinggi (66\%) sebanyak 100 responden yang menyatakan 
sering mencari dan menelusur informasi dan persentase terendah (3\%) sebanyak 5 responden yang menyatakan tidak pernah mencari dan menelusur informasi.

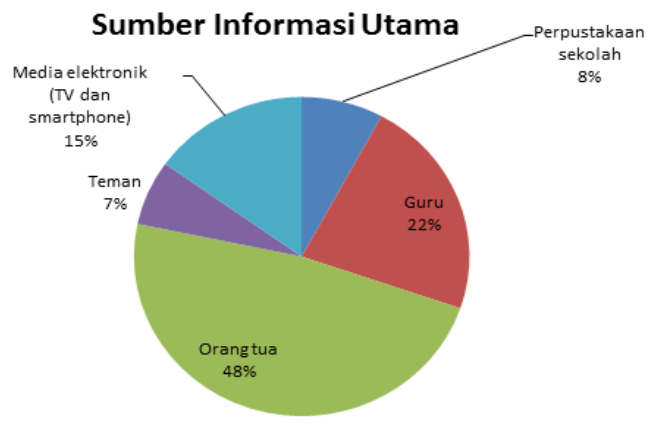

Berdasarkan tabel di atas dengan total persentase 100\% dan responden sebanyak 152 orang menghasilkan jabaran sebagai berikut sebanyak 12 responden (8\%) menyatakan bahwa perpustakaan sekolah merupakan sumber informasi utama oleh siswa yang berkebutuhan khusus. Sebanyak 34 responden (22\%) menyatakan guru merupakan sumber informasi utama oleh siswa yang berkebutuhan khusus. Selanjutnya, 73 responden (48\%) menyatakan orang tua merupakan sumber informasi utama oleh siswa yang berkebutuhan khusus. Sebanyak 10 responden (7\%) menyatakan teman merupakan sumber informasi utama oleh siswa yang berkebutuhan khusus dan terakhir ada 23 responden (15\%) menyatakan media elektronik (TV dan smartphone) merupakan sumber informasi utama oleh siswa yang berkebutuhan khusus. Kesimpulan dari tabel di atas bahwa persentase tertinggi (48\%) sebanyak 73 responden menyatakan orang tua sumber informasi utama oleh siswa yang berkebutuhan khusus dan persentase terendah (7\%) sebanyak 10 responden menyatakan bahwa teman merupakan sumber informasi utama oleh siswa yang berkebutuhan khusus.

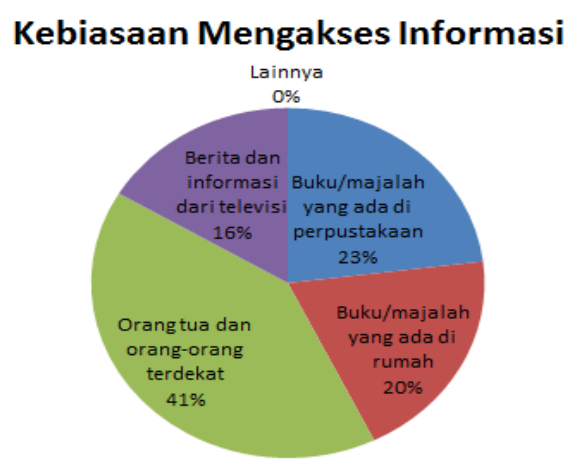


Berdasarkan tabel di atas dengan total persentase 100\% dan responden sebanyak 152 orang menghasilkan jabaran sebagai berikut sebanyak 35 responden (23\%) menyatakan biasa mengakses informasi dari buku/majalah yang ada di perpustakaan . Selanjutnya, 30 responden $(20 \%)$ menyatakan biasa mengakses informasi dari buku/majalah yang ada di rumah. Sebanyak 62 responden $(41 \%)$ menyatakan biasa mengakses informasi dari orang tua dan orang-orang terdekat. Selanjutnya, sebanyak 25 responden (16\%) menyatakan biasa mengakses informasi dari berita dan informasi dari televisi. Terakhir, tidak ada responden $(0$ $\%)$ menyatakan alasan lain dalam kebiasaan mengakses informasi. Kesimpulan dari tabel diatas bahwa persentase tertinggi (41\%) sebanyak 62 responden menyatakan biasa mengakses informasi dari orang tua dan orang-orang terdekat. dan persentase terendah $(0 \%)$ tidak ada responden yang menyatakan alasan lain dalam kebiasaan mengakses informasi.

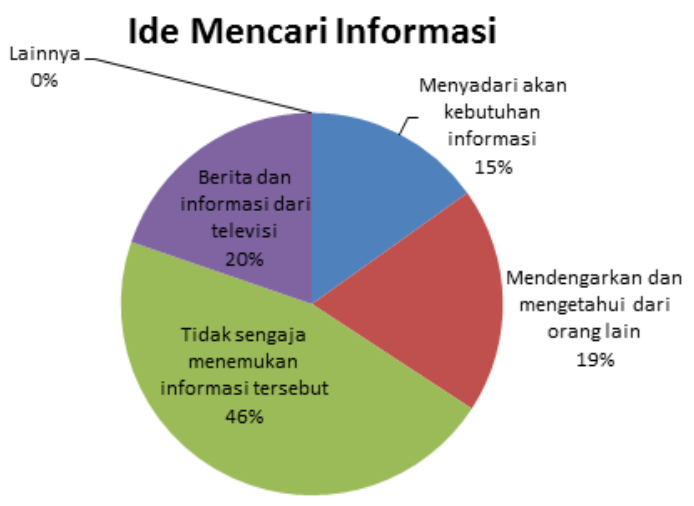

Berdasarkan tabel di atas dengan total persentase 100\% dan responden sebanyak 152 orang menghasilkan jabaran sebagai berikut sebanyak 23 responden (15\%) menyatakan ide mencari informasi karena menyadari akan kebutuhan informasi. Selanjutnya, 29 responden (19\%) menyatakan ide mencari informasi karena mendengarkan dan mnegetahui dari orang lain. Sebanyak 70 responden (46\%) menyatakan ide mencari informasi karena tidak sengaja menemukan informasi tersebut. Selanjutnya, sebanyak 30 responden (20\%) menyatakan ide mencari informasi karena berita dan informasi dari televisi. Terakhir, tidak ada responden ( 0 $\%)$ menyatakan alasan lain dalam ide mencari informasi. Kesimpulan dari tabel diatas bahwa persentase tertinggi (46\%) sebanyak 70 responden menyatakan ide mencari informasi karena tidak sengaja menemukan informasi tersebut dan persentase terendah $(0 \%)$ tidak ada responden yang menyatakan alasan lain dalam ide mencari informasi. 


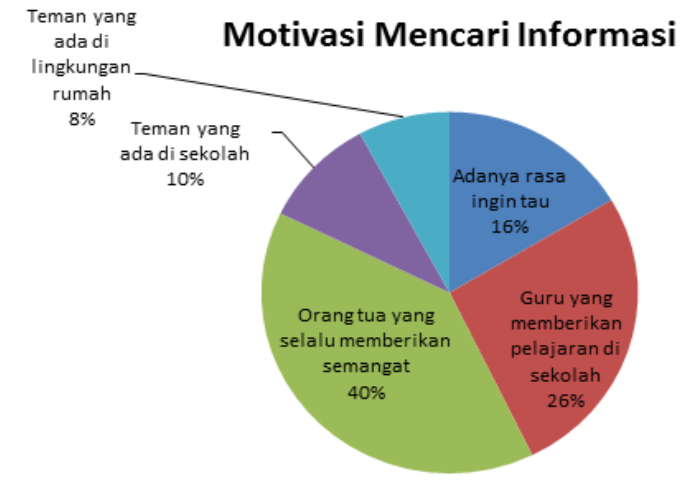

Berdasarkan tabel di atas dengan total persentase $100 \%$ dan responden sebanyak 152 orang menghasilkan jabaran sebagai berikut sebanyak 25 responden (16\%) menyatakan motivasi mencari informasi karena adanya rasa ingin tau. Selanjutnya, 40 responden (26\%) menyatakan motivasi mencari informasi karena berasal dari guru yang memberikan pelajaran di sekolah. Sebanyak 60 responden (40\%) menyatakan motivasi mencari informasi berasal dari orang tua yang selalu memberikan semangat. Selanjutnya, sebanyak 15 responden (10\%) menyatakan motivasi mencari informasi berasal dari teman yang ada di sekolah. Terakhir, sebanyak 12 responden $(8 \%)$ menyatakan motivasi mencari informasi berasal dari teman yang ada di lingkungan rumah. Kesimpulan dari tabel diatas bahwa persentase tertinggi (40\%) sebanyak 60 responden menyatakan motivasi mencari informasi berasal dari orang tua yang selalu memberikan semangat dan persentase terendah (8\%) sebanyak 12 responden menyatakan motivasi mencari informasi berasal dari teman yang ada di lingkungan rumah.

\section{Cara Memahami Informasi}

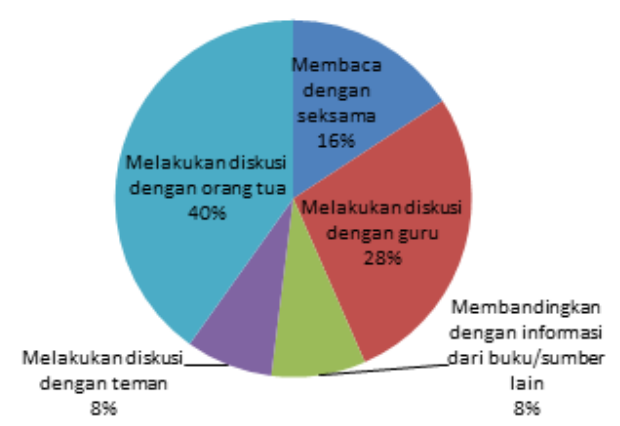


Berdasarkan tabel di atas dengan total persentase 100\% dan responden sebanyak 152 orang menghasilkan jabaran sebagai berikut sebanyak 24 responden (16\%) menyatakan bahwa cara memahami informasi dengan membaca dengan seksama. Selanjutnya, 42 responden (28\%) menyatakan bahwa cara memahami informasi dengan melakukan diskusi dengan guru. Kemudian, 13 responden (8\%) menyatakan bahwa cara memahami informasi dengan membandingkan dengan informasi dari buku/sumber lain, sebanyak 12 responden (8\%) menyatakan bahwa cara memahami informasi dengan melakukan diskusi dengan teman dan yang terakhir 61 responden $(40 \%)$ menyatakan bahwa cara memahami informasi dengan melakukan diskusi dengan orang tua. Kesimpulan dari tabel di atas bahwa persentase tertinggi (60\%) sebanyak 61 menyatakan bahwa cara memahami informasi dengan melakukan diskusi dengan orang tua dan persentase terendah (8\%) sebanyak 8 responden menyatakan bahwa cara memahami informasi dengan melakukan diskusi dengan teman.

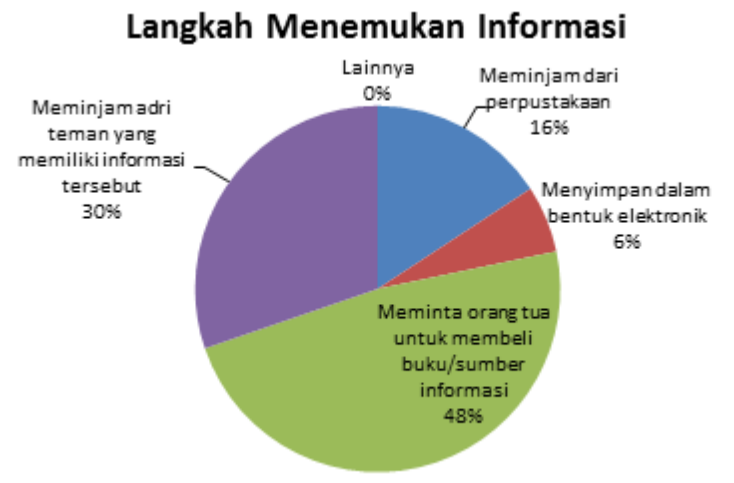

Berdasarkan tabel di atas dengan total persentase 100\% dan responden sebanyak 152 orang menghasilkan jabaran sebagai berikut sebanyak 24 responden (16\%) menyatakan bahwa langkah memahami informasi dengan meminjam dari perpustakaan. Selanjutnya, 9 responden (6\%) menyatakan bahwa langkah memahami informasi dengan menyimpan dalam bentuk elektronik. Kemudian, 73 responden (48\%) menyatakan bahwa langkah memahami informasi dengan meminta orang tua untuk membeli buku/sumber informasi, sebanyak 46 responden (36\%) menyatakan bahwa langkah memahami informasi dengan meminjam dari teman yang memiliki informasi tersebut dan yang terakhir tidak ada responden $(0 \%)$ menyatakan alasan lain dalam langkah memahami informasi. Kesimpulan dari tabel di atas 
bahwa persentase tertinggi (48\%) sebanyak 73 responden menyatakan bahwa langkah memahami informasi dengan meminta orang tua untuk membeli buku/sumber informasi dan persentase terendah tidak ada responden $(0 \%)$ yang menyatakan alasan lain dalam langkah memahami informasi.

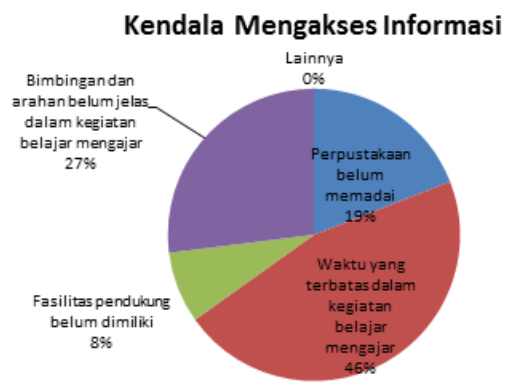

Berdasarkan tabel di atas dengan total persentase $100 \%$ dan responden sebanyak 152 orang menghasilkan jabaran sebagai berikut bahwa sebanyak 29 responden (19\%) menyatakan bahwa kendala mengakses informasi karena perpustakaan belum memadai. Selanjutnya, 70 responden (46\%) menyatakan bahwa kendala mengakses informasi karena waktu yang terbatas dalam kegiatan belajar mengajar, selain itu, 12 responden (8\%) menyatakan bahwa kendala mengakses informasi karena fasilitas pendukung belum dimiliki dan sebanyak 41 responden (27\%) menyatakan bahwa kendala mengakses informasi karena bimbingan dan arahan belum jelas dalam kegiatan belajar mengajar. Kemudian, tidak ada responden $(0 \%)$ yang menyatakan alasan lain dalam kendala mengakses informasi. Kesimpulan dari tabel di atas bahwa persentase tertinggi (46\%) sebanyak 70 responden menyatakan bahwa kendala mengakses informasi karena waktu yang terbatas dalam kegiatan belajar mengajar dan persentase terendah menunjukkan tidak ada responden (0\%) yang menyatakan alasan lain dalam kendala mengakses informasi.

\section{Peran Guru dan Pustakawan di Perpustakaan dalam Penelusuran Informasi}

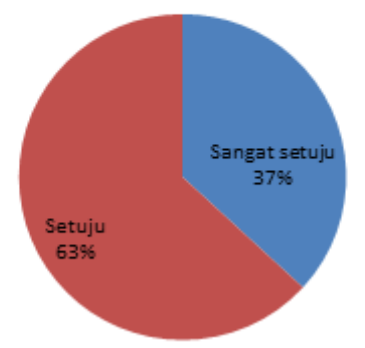


Berdasarkan tabel di atas dengan total persentase 100\% dan responden sebanyak 152 orang menghasilkan jabaran sebagai berikut sebanyak 56 responden (37\%) menyatakan sangat setuju bahwa guru dan pustakawan di perpustakaan berperan dalam penelusuran informasi. Selanjutnya, 90 responden (63\%) menyatakan setuju bahwa guru dan pustakawan di perpustakaan berperan dalam penelusuran informasi. Kemudian, tidak ada responden $(0 \%)$ yang menyatakan guru dan pustakawan di perpustakaan tidak berperan berperan dalam penelusuran informasi. Kesimpulan dari tabel di atas bahwa persentase tertinggi 90 responden (63\%) menyatakan setuju bahwa guru dan pustakawan di perpustakaan berperan dalam penelusuran informasi dan persentase terendah tidak ada responden $(0 \%)$ yang menyatakan guru dan pustakawan di perpustakaan tidak berperan berperan dalam penelusuran informasi.

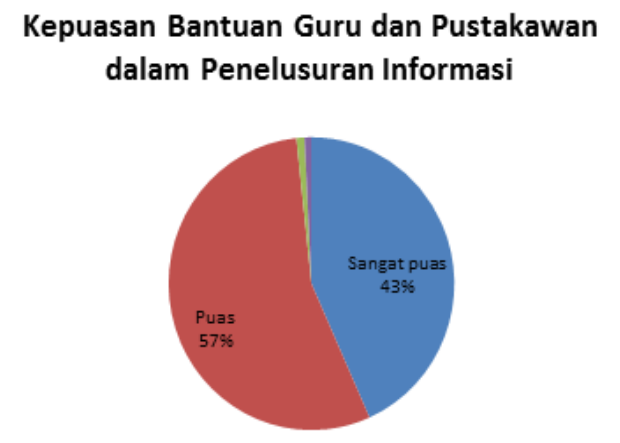

Berdasarkan tabel di atas dengan total persentase $100 \%$ dan responden sebanyak 152 orang menghasilkan jabaran sebagai berikut sebanyak 67 responden (43\%) menyatakan sangat puas akan bantuan guru dan pustakawan di perpustakaan dalam penelusuran informasi. Selanjutnya, 85 responden (57\%) menyatakan puas akan bantuan guru dan pustakawan di perpustakaan dalam penelusuran informasi. Kemudian, tidak ada responden (0\%) yang menyatakan tidak puas akan bantuan guru dan pustakawan di perpustakaan dalam penelusuran informasi. Kesimpulan dari tabel di atas bahwa persentase tertinggi 85 responden (57\%) menyatakan puas akan bantuan guru dan pustakawan di perpustakaan dalam 
penelusuran informasi dan persentase terendah tidak ada responden $(0 \%)$ yang menyatakan tidak puas akan bantuan guru dan pustakawan di perpustakaan dalam penelusuran informasi.

\section{Kesimpulan}

Berdasarkan hasil penelitian diperoleh kesimpulan bahwa sebagian besar responden, yakni 100 responden (66\%) sering mencari dan menelusur informasi. Selain itu, hampir setengah dari jumlah responden $(41 \%)$ menyatakan biasa mengakses informasi dari orang tua dan orang-orang terdekat. Dalam hal ide mencari informasi, sebanyak 70 responden $(46 \%)$ menyatakan ide mencari informasi karena tidak sengaja menemukan informasi tersebut dan sebanyak 60 responden (40\%) menyatakan motivasi mencari informasi berasal dari orang tua yang selalu memberikan semangat. Dalam hal pemahaman informasi, sebagian besar responden (60\%) menyatakan bahwa cara memahami informasi dengan melakukan diskusi dengan orang tua. Kemudian, langkah memahami informasi menunjukkan bahwa sebanyak 73 responden $(48 \%)$ menyatakan bahwa langkah memahami informasi dengan meminta orang tua untuk membeli buku/sumber informasi.

Kendala dalam mengakses informasi ditemukan data bahwa sebanyak 70 responden (46\%) menyatakan bahwa kendala mengakses informasi karena waktu yang terbatas dalam kegiatan belajar mengajar. Sebagian besar responden yakni, sebanyak 90 responden (63\%) menyatakan setuju bahwa guru dan pustakawan di perpustakaan berperan dalam penelusuran informasi . data yang terkahir menunjukkan bahwa hamper mayoritas responden, yakni 85 responden $(57 \%)$ menyatakan puas akan bantuan guru dan pustakawan di perpustakaan dalam penelusuran informasi.

\section{Daftar Pustaka}

Gendina, N.I.: Information Literacy or Information Culture: Separation for Unity: Russian Research Results. In: World Library and Information Congress: 70th IFLA General Conference and Council, Buenos Aires, Argentina, August 22-27 (2004)

Ginman,A. 1987. Information Culture and Bussines Performance. IATUL Quarterlv, Vol 2. No.2. P 93-106.

McLeod, Raymond Jr dan Schell, George. 2001. Management Information System. London: Prentice International Hall, Inc.

Sulistyo-Basuki. 2004. Pengantar Dokumentasi. Bandung: Rekayasa Sains.

Suroso, Arif Imam dan Aji Hermawan. 1998. Manajemen Budaya Informasi. Amal Agrimedia. Vol.4 No 3. ISSN: 0853-846-8.

Wang, Mei -Yu. 2005. The Impact of Information Culture on Managing Knowledge: A Double Case Study of Pharmaceutical Manufacturers in Taiwan. Library Review. Vol. 55. No 3 p 209-2 221. 
